\title{
Ilmu Balaghah: Tasybih dalam Manuskrip "Syarh Fī Bayān al-Majāz wa al-Tasybīh wa al-Kināyah"
}

\author{
Iin Suryaningsih ${ }^{1}$, Hendrawanto $^{2}$ \\ ${ }^{1,2}$ Program Studi Sastra Arab, Fakultas Sastra, Universitas Al Azhar Indonesia \\ Kompleks Masjid Agung Al-Azhar, Jl.Sisinganmangaraja, Kebayoran Jakarta Selatan 12110 \\ Penulis untuk Korespondensi/E-mail: iin.suryaningsih@uai.ac.id
}

\begin{abstract}
Abstrak - Salah satu kategori manuskrip nusantara adalah manuskrip yang keberadaannya di Indonesia berasal dari pertukaran ilmu para ulama nusantara yang belajar ke Makkah dan Madinah lalu kembali ke tanah air membawa naskah berbahasa arab, kemudian naskah tersebut di pelajari oleh masyarakat Indonesia sebagai bahan kajian keilmuan.Ungkapan tasybih populer di pakai oleh kalangan pujangga arab sejak masa keemasan karya sastra terukir dalam sejarah periode Jahiliyah. Gaya bahasa tasybih merupakan upaya penutur untuk mengungkapkan sesuatu dengan menyerupakan hal yang ia maksud dengan sesuatu lain yang memilki kesamaan efek dan akibat. Ilmu bayan secara bahasa adalah penjelasan, penyingkapandan keterangan. Sedangkan secara istilahilmu bayan berarti dasar atau kaidah yang menjelaskan keinginan tercapainya satu makna dengan macam-macam gaya bahasa.Metode yang di gunakan dalam penelitian ini di bagi menjadi dua tahap, pertama : metode filologi, di gunakan untuk membaca dan menganalisis teks dalam manuskrip secara tepat, dan kedua : metode deskriptif dengan pendekatan objektif, yaitu metode yang akan fokus hanya pada satu teks saja, menganalisis dan menguraikan isi teks secara menyeluruh dan jelas. Penelitian ini diharapkan dapat melengkapi kajian-kajian sebelumnya serta memperluas wawasan mengenai khazanah ilmu yang terkandung dalam manuskrip. Dengan begitu, analisis mengenai informasi keilmuan yang terdapat dalam manuskrip dapat dikembangkan dan dikaji secara lebih lanjut.
\end{abstract}

Kata Kunci - Manuskrip, Filologi, Tasybih, Bayan,

Abstract - One of the categories of nusantara's manuscripts is a manuscript whose existence in Indonesia, comes from exchanges of science scholars who studied the archipelago to Mecca and Medina and then returned to carrying the Arabic script, then the script is a learned society scientific studies in Indonesia.Expression of tasybih popular used by the Arabic poets since the golden age of literature in history etched in the period of Ignorance. The language style of tasybih is an attempt to express something with speakers equate the things he meant by something else that has similarities to the effects and consequences. Bayan science in language is the explanation, disclosure and description. While the term science in bayan means basic or rule that describes the desire to achieve the one meaning with various styles of language. The method used in this research is divided into two stages, the first method is Philology, used for reading and analyzing texts in manuscript precisely, and second: descriptive methodswith objective approach, amethod which will focus only on a single text, analysis and elaborate on the contents of the text thoroughly and clearly. This research is expected to complement previous studies as well as broaden insights into the corpus of knowledge that is contained in the manuscript. Thus, the analysis of the scientific information contained in the manuscript could be developed and examined in more details. 


\section{PENDAHULUAN}

Salah satu bidang ilmu dalam kajian Sastraarab adalah ilmu balaghah atau popular di kenal sebagai stilistika arab. Secara umum, balaghah adalah ilmu yang mempelajari tentang bagaimana mengolah kata atau susunan kalimat bahasa arab yang indah namun tetap menjaga kejelasan makna dengan juga memperhatikan situasi dan kondisi saat uangkapan tersebut terjadi. Ilmu balaghah terbagi menjadi 3 (tiga) cabang ilmu besar, yaitu : ilmu bayan, ilmu ma'ani dan ilmu badi'(Ali Jarim dan Musthafa:1998). Masingmasing dari ketiga cabang ilmu tersebut memilki kekhususan gaya bahasa.

Fokus penelitian ini adalah kajian dari cabang Ilmu bayan yaitu tasybih, Secara bahasa bayan di artikan kiasan, menurut kamus besarbahasa Indonesia (KBBI) adalah perbandingan, persamaan/ibarat, sindiran atau analogi. Melalui pengertian singkat ini,gaya bahasa kiasan yang di bahas dalam ilmu bayan pada dasarnya di bentuk berdasarkan perbandingan dengan analogi karena memiliki kesamaan atau hubungan satu dengan yang lainnya, seperti hubungan sebab akibat dll, berbeda dengan dua cabang ilmu balaghah lainnya yaitu ilmu ma'ani dan ilmu badi'(ali Jarim \& Musthafa :1998)

Ungkapan tasybih popular di pakai oleh kalangan pujangga arab sejak masa keemasan karya sastra terukir dalam sejarah di periode Jahiliyah. Gaya bahasa tasybih merupakan upaya penutur untuk mengungkapkan sesuatu dengan menyerupakan hal yang ia maksud dengan sesuatu lain yang memilki kesamaan efek dan akibat (Shaikhun:1988)

Pertukaran budaya dan bahasa yang tejadi secara natural saat proses islam masuk ke Indonesia dan saat maraknya ulama Nusantara yang menginjakkan kakinya ke negara Timur Tengah dengan tujuan ibadah dan menuntut ilmu agama, ini adalah proses dari sebuah perjalanan panjang yang menghasilkan ilmu pengetahuan. Dokumen yang di bawa ke tanah air dan karangan yang muncul dari pemikiran mendalam para ulama nusantara itu sendiri, di tuangkan dalam media tulis yang masih sangat terbatas kala itu seperti daun lontar, kayu dll lalu sejarah menyebutnya sebagai manuskrip.(Pujiastuti:2016:9)

\section{LANDASAN TEORI}

\section{Manuskrip dan Nusantara}

Pertukaran budaya dan bahasa yang tejadi secara natural saat proses islam masuk ke Indonesia dan saat maraknya ulama Nusantara yang menginjakkan kakinya ke negara Timur Tengah dengan tujuan ibadah dan menuntut ilmu agama, ini adalah proses dari sebuah perjalanan panjang yang menghasilkan ilmu pengetahuan. Dokumen yang di bawa ke tanah air dan karangan yang muncul dari pemikiran mendalam para ulama nusantara itu sendiri, di tuangkan dalam media tulis yang masih sangat terbatas kala itu seperti daun lontar, kayu dll lalu sejarah menyebutnya sebagai manuskrip.(Pujiastuti:2016:9)

Istilah "naskah" sangat identik penggunaannya dengan penyebutan istilah "manuskrip", karena dalam manuskrip di tema tertentu misalnya, terdiri dari beberapa bundel naskah. Naskah di maknai sebagai semua bahan tulisan tangan peninggalan nenek moyang kita pada kertas, lontar, kulit kayu dan rotan. Tulisan tangan pada kertas itu biasanya dipakai pada naskahnaskah yang berbahasa Melayu dan yang berbahasa Jawa; Rotan hanya dipakai pada naskah-naskah yang berbahasa Jawa dan Bali. Kulit kayu dan rotan biasanya digunakan pada naskah-naskah berbahasa Batak. Dalam bahasa Latin naskah ini disebut codex, dalam bahasa Inggris disebut manuscript, dan dalam bahasa Belanda disebut dengan istilah handschrift.

Nisbat kata"Nusantara" dalam term manuskrip di Indonesia, adalah sebagai ciri bahwa kajian yang terdapat di dalam teks tersebut berbahasa lokal seperi Sunda, Jawa, Sumatra dan Kalimantan, atau terkait dengan proses islamisasi ke Indonesia yang melibatkan terjadinya asimilasi budaya dan bahasa asing (khususnya gujarat asal Arab dan India) ke bumi nusantara.

\section{Sejarah Ilmu Balaghah}

Perkembangan kesusastraan Arab pada era jahiliyah diwarnai oleh adanya perkembangan berbagai bentuk sastra, baik prosa maupun puisi yang dikembangkan oleh orang-orang Arab pada masa itu. Perkembangan tersebut didukung juga oleh adanya berbagai kegiatan yang berlangsung pada musim haji setiap tahunnya, dengan diadakannya berbagai perlombaan pidato dan perlombaan membaca 
sya'ir, yang diadakan di berbagai pusat kegiatan pada waktu itu, seperti di Suq 'Ukkazh. Kegiatan-kegiatan seperti itu memberi peluang yang besar bagi para ahli sya'ir untuk mengembangkan bahasa dan gaya bahasa mereka dengan ungkapan-ungkapan yang menarik, baik dari segi zahir lafal, keindahan kata yang digunakan, maupun kandungan maknanya

Pengaruh al-Qur'an terhadap Balaghah 'Arabiyyah tersebut begitu nyata. Hal tersebut ditandai dengan dijadikannya al-Qur'an sebagai objek kajian dalam diskursus-diskursus kebalaghahan yang melahirkan karya-karya besar seperti Kitab Majaz Al-Qur'an karya Abu 'Ubaidah (w. $207 \mathrm{H}$ ) yang ditulis karena adanya ketidakpahaman Ibrahim bin Isma'il terhadap penggunaan tasybih dalam penggambaran sifat syajarat al-Zaqqum (makanan penduduk neraka) dalam surat alshaffat.

Sampai masa permulaan Islam ini keberadaan ilmu Balaghah sebagai suatu disiplin ilmu yang utuh seperti saat ini belum terkodifikasi, namun ia terus mengalami perkembangan sedikit demi sedikit. Diawali dengan kajian sastra terhadap beberapa sya'ir dan pidato-pidato orang Jahiliah, dilanjutkan dengan mengulas sya'ir dan sastra pada masa awal Islam, sampai kepada masa pemerintahan Daulah Umayah, ia terus mengalami perkembangan yang menggembirakan. (Syakir:1999)

Perkembangan Balaghah yang semakin baik tersebut ditandai dengan munculnya para tokoh yang kompeten dan karya-karya besar mereka pada abad ke-III H, seperti Abu 'Ubaidah (w. $211 \mathrm{H}$ ), Ibnu Qutaibah (w. $276 \mathrm{H}$ ), Ibnu Hasan al-Rumani (w. $284 \mathrm{H}$ ), al-Farra' (w.207 H), dan Al-Jahizh (w. 255 H). Abu 'Ubaidah menyusun sebuah kitab tentang Majaz al-Qur'an yang bernama Ilmu Majazil Qur'an. Ibnu Quthaibah menulis kitab Ta'wil Musykil al-Qur'an, dan Al-Farra' menulis kitab Ma'anil Qur'an yang meski kebanyakan berisi kajian ilmu Nahwu, tapi juga menyinggung kajian ilmu Balaghah. Sedangkan al-Rumani menyusun kitab AnNaktu Fi I'jazil Qur'an.[18] Dan Al-Jahizh dipandang sebagai tokoh yang sangat berjasa dalam sejarah perkembangan ilmu Balaghah secara umum dan ilmu Bayan secara khusus, lewat karya tulisnya yang berjudul al-Bayan wa al-Tabyin.

\section{Pengertian Ilmu Balaghah}

Secara etimologi berasal dari kata "ba-la-gha "بَّلَغَ" yaitu sampai atau ujung.Balaghah berarti sampainya ide dan pikiran yang ingin kita ungkapkan kepada lawan bicara dengan hasil pertimbangan kesesuaian makna-maknanya, dan situasi serta kondisi saat ungkapan itu terjadi. Ungkapan yang sarat dengan balaghah muncul hasil olah pikir yang tidak sederhana, keterlibatan emosi, rasa, pemilihan diksi yang tepat dan imajinasi yang kuat adalah beberapa unsure dalam keilmuan sastra, balaghah salah satunya (Syukron : 1999).

Dalam kajian sastra, balaghah ini menjadi sifat sebuah ungkapan dan penuturnya, maka lahir lah sebutan ungakapan sastra (kalam baligh) dan penutur sastra (mutakallim baligh). Menurut Abd al-Qadir Husen (1984) balaghah sangat memperhatikan kesesuaian kalimat dengan kondisi dan situasi lawan bicara. Nilai tuturan yang mengandung balaghah bergantung kepada sejauh mana ungkapan tersebut dapat memenuhi tuntutan situasi dan kondisinya.

\section{Cabang Ilmu Balaghah}

Ada 3 (tiga) cabang ilmu balaghah yang secara singkat sudah penulis singgung pada pembahasan sebelumnya, yaitu ilmu bayan, ilmu ma'ani dan ilmu badi'. Objek kajian ketiga ilmu ini saling melengkapi.

Ilmu bayan secara bahasa adalah penjelasan, penyingkapandan keterangan. Sedangkan secara istilahilmu bayan berarti dasar atau kaidah yang menjelaskan keinginan tercapainya satu makna dengan macam-macam gaya bahasa (al-Hasyimi:1994). Dari pengertian tentang ilmu bayan, yang berisi macam-macam cara untuk menyampaikan makna, objek kajiannya berkisar pada berbagai corak gaya bahasa yang merupakan metode penyampaian makna yang meliputi tasybih, majaz dan kinayah.

Ilmu ma'ani adalah dasar-dasar dan kaidah yang menjelaskan pola kalimat berbahasa arab agar bisa di sesuaikan dengan kondisi dan situasi. Tujuan ilmu ma'ani ini adalah sebagai upaya menghindari kesalahan dalam pemaknaan yang di kehendaki penutur yang di sampaikan kepada lawan bicara. Dari istilah ma'ani yang menyelaraskan konteks dan teks, maka objek kajian ilmu ini menitikberatkan 
pada pola kalimat berbahasa arab di lihat dari pernyataan makna awal dan bukan makna yang di maksud oleh penutur. Objek kajian ilmu ma'ani diantaranya adalah kalam khabar dan insya', gaya bahasa I'jaz, ithnab dan musawah.

Ilmu Badi' secara bahasa adalah sebuah kreasi atau penciptaan, secara istilah ilmu badi' adalah ilmu yang mempelajari beberapa model keindahan stilistika, ornamen dalam kalimat yang akan membuat kalimat tersebut indah jika di tinjau dari kata dan maknanya. Ilmu badi' ini memiliki dua kajian, yaitu muhassinat lafdziyyah (analisis keindahan struktur kata) dan muhassinat ma'nawiyah.(analisis keindahan struktur makna).

\section{Tasybih}

Sebagaimana pemaparan singkat sebelumnya, bahwa kajian ilmu balaghah memiliki 3 (tiga) cabang ilmu besar, yaitu : ilmu Bayan, ilmu Ma'ani dan ilmu Badi' yang ketiganya ini akan saling melengkapi. Bagian dari kajian ilmu Bayan adalah majaz dan tasybih.

Tasybih secara bahasa artinya menyerupakan (Hasyimi:1991:247). Dalam istilah balaghah, tasybih adalah: "menyamakan satu hal dengan hal lain dengan menggunakan perangkat (sarana) tasybih untuk mengumpulkan keduanya". Tasybih juga dapat di artikan : "menyerupakan dua perkara atau lebih yang memiliki kesamaan sifat karena ada tujuan yang di kehendaki oleh penutur".

Melalui pengantar tentang tasybih, berikut ini adalah rukun/unsur penting dalam tasybih, keberadaan masing-masing unsure akan sangat penting untuk mensinergikan sebuah ungkapan. Dengan istilah lain, bahwa unsure ini akan selalu ada dalam gaya bahasa tasybih baik secara eksplisit maupun implicit. Dan rukun tersebut adalah sebagai berikut :

1. Al-Musyabbah (sesuatu yang di bandingkan dengan sesuatu lainnya karena ada persamaan sifat antara keduanya)

2. Al-Musyabbah bih (sesuatu yang sifatnya di jadikan perbandingan)

3. 'Adat al-Tasybih (perangkat untuk menggabungkan dua persamaan sifat yang ada)

4. Wajh al-Syibh (kesamaan sifat yang di perbandingkan)

Dalam pembentukan ungkapan tasybih, ada 2 (dua) rukun yang wajib di sebutkan dan tidak boleh di hilangkan yaitu musyabbah dan musyabbah bih, jika salah satu dari kedua rukun tersebut tidak di sebutkan maka ungkapan tersebut tidak dapat di sebut tasybih.

\section{Pembagian Tasybih}

Para ahli balaghah, membagi tasybih ke dalam beberapa bagian berdasarkan rukun-rukunnya. Pembagian ini di lihat dari beberapa sudut pandang sehingga bisa saja satu dengan lainnya akan ada perbedaan dan persamaan dan hal tersebut tidaklah mendasar, karena hal terpenting yaitu memahami masing-masing bagian tasybih.

1. Pembagian tasybih berdasarkan wajh alsyibh dan 'adat al-tasybih :

a. Tasybih Mursal adalah tasybih yang 'adat al-tasybihnya di sebutkan dalam ungkapan tersebut, contoh :

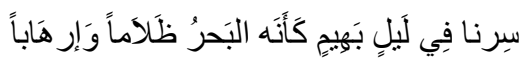

"kami berjalan di malam yang gelap gulita, sepertinya malam itu bagaikan laut yang gelapdan mencekam"

Dalam contoh di atas, penyair menyerupakan malam yang gelap dengan kondisi laut yanggelap mencekam. Jika kita perhatikan sya'ir di atas, si penuturnya menyertakan 'adat al-tasybih (perangkat) untuk menggabungkan keserupaan dua hal. Perangkat yang di maksud di atas adalah berupa huruf "ka-anna".

b. Tasybih Muakkad adalah tasybih yang 'adat al-tasybihnya di hilangkan.

Contohnya :

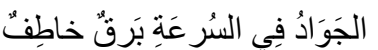

" kecepatan kuda itu bagaikan kilat yang menyambar".

c. Tasybih Mufasshal adalah tasybih yang wajh al-syibhnya jelas di sebutkan dalam rangkaian sebuah ungkapan.

Contohnya :

“ perkataan bagaikan mutiara dari sisi kebaikannya"

d. Tasybih Mujmal adalah tasybih yang wajh al-syibhnya tidak jelas di sebutkan dalam rangkaian sebuah ungkapan.

"buku layaknya seorang teman/sahabat"

e. Tasybih Baligh adalah tasybih yang tidak menyebutkan 'adat al-tasybih dan wajh al- 
syibhnya dalam rangkaian sebuah ungkapan.

Contohnya :

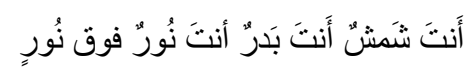

" Engkau adalah matahari, Engkau adalah bulan, Engkau adalah cahaya di atas cahaya"

2. Pembagian tasybih berdasarkan bentuk wajh al-syibhnya, di bagi menjadi :

a. Tasybih Ghair al-Tamtsil, adalah tasybih yang wajh al-syibhnya tidak merupakan gambaran sesuatu yang tunggal (tidak berbilang).

Contohnya :

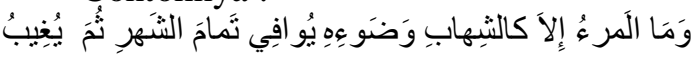
“ tidaklah seseorang itu seperti bulan dan cahayanya, yang menempati sebulan penuh kemudian menghilang “

Pada contoh di atas, wajh al-syibhnya adalah kondisi“cepatnya binasa”, keadaan tersebut di ambil oleh penyair dari pemaknaan penggalan bait terakhir pada sya'ir itu. Munculnya kalimat " تمام الشهر adalah proses dari keadaan cahaya bulan yang berangsur-angsur, yaitu dimulai dari kemunculan bulan pertama "هلال" sampai bulan purnama "بدر". Kondisi demikian tetap di kategorikan tunggal (tidak berbilang).

b. Tasybih al-Tamtsil, adalah tasybih yang wajh al-syibhnya merupakan gambaran dari sesuatu yang tidak tunggal (berbilang).

Contohnya :

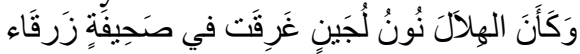

"bulan sabit bagaikan huruf nun yang berwarna perak yang tenggelam dalam kertas berarsirberwarna biru"

Pada contoh di atas, wajh al-syibhnya adalah kondisi "warna putih yang di celupkan ke dalam warna biru". Kondisi tersebut di ambil oleh penyair dari pemaknaan bait secara sempurna.

c. Tasybih yang keluar dari kaidah

a. Tasybih Dhimniy, adalah tasybih yang kedua tharafnya (musyabbah dan musyabbah bihnya) tidak di rangkai dalam bentuk tasybih seperti yang sudah sebelumnya di jelaskan, dan bahwa susunan kalimatnya tidak di sertakan 'adat al-tasybih, hanya saja keduanya berdampingan dalam susunan kalimat.

Contohnya :

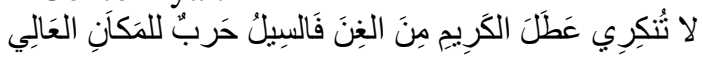
" jangan kau ingkari bila melihat orang dermawan yang tidak memiliki kekayaan, sebab banjir adalah musuh dari tempat yang tinggi”.

\section{Pengantar Filologi}

Kebutuhan peneliti yang sangat mendasar terhadap metodologi filologi adalah saat peneliti harus berhadapan dengan data primer berupa manuskrip atau naskah tulis tangan. Dalam istilah arab, kajian filologi di kenal dengan sebutan tahqiq al-nushus. Tahqiq secara bahasa adalah penentuan, analisis, evaluasi dan proses edit sebuah teks. Sederhananya, data yang ada dalam manuskrip akan di tinjau dari beberapa aspek terlebih dahulu untuk membuktikan validitas isinya melalui tahapan-tahapan yang di tentukan oleh para filolog.

\section{Tahapan Penelitian Filologi}

Secara personal maupun tingkat institusi/lembaga, kebutuhan tentang penerapan metodologi filologi terhadap suatu teks adalah untuk membuktikan item penting dalam sebuah karya, tahapan yang di lakukan berupa :

1. Analisis judul teks : Umumnya, kumpulan manuskrip berada dalam bundel-bundel naskah yang berisi beberapa tema/judul. Kondisi tersebut karena proses pelepasan judul manuskrip dengan judul yang lain harus melalui tahapan analisis terhadap judul masing-masing teks. Berikut adalah faktor yang mendasari perlunya di lakukan analisis terhadap judul manuskrip,yaitu : (1) hilangnya lembar pertama teks yang memuat judul naskah(2) judul yang tidak jelas karena ada perubahan pada tinta atau kertas naskah (3) judul yang salah penisbatan penulisnya, atas tujuan tertentu baik sengaja ataupun tidak, seperti ketidaktahuan si penyalin naskah terhadap judul dan penulis utama naskah tersebut

2. Analisis penulis utama teks : Peneliti tidak seharusnya merasa cukup puas dengan temuan nama penulis utama teks yang ada dalam lembar pertama naskah, hal tersebut harus di analisis dan di buktikan kembali kebenarannya melalui penelusuran 
beberapa referensi terkait. Dengan demikian, analisis nama penulis teks merupakan tahap penting dalam penyuntingan teks manuskrip

3. Analisis koherensi antara judul dengan penisbatan kepada penulis utama : masalah yang kerap kali terjadi dalam manuskrip arab karya ulama arab adalah keliru menisbatkan nama penulis pada teks tertentu karena adanya kesamaan nama penulis dengan judul buku yang berbeda, ataupun sebaliknya.

4. Analisis isi teks : tahap ini merupakan tahap inti dari proses penyuntingan teks. Peneliti di harapkan dapat mengungkapkan semua informasi yang di bawa oleh penulis baik implisit atau eksplisit. Peneliti juga di harapkan mampu menemukan benang merah sejarah yang menjadi titik temu masa penulisan teks dengan manfaat yang dapat di bangun masa kini dan akan datang.

\section{ANALISISTASYBIH DALAM MANUSKRIP : \\ "Syarh Fì Bayān al-Majāz wa al-Tasybīhwa al-Kināyah"}

\section{Pengantar}

Peneliti akan menguraikan analisis tema tasybih yang di bahas dalam manuskrip nusantara berjudul "Syarh F̄̄ Bayān al-Majāz wa al-Tasybīhwa al-Kināyah”. Tahapan metode yang akan di gunakan di bagi ke dalam 2 (dua) tahapan penting, yaitu (1) penerapan metodologi filologi : untuk membaca dan menganalisis teks secara utuh, dan (2) metode deskriptif dengan pendekatan objektif : untuk mengurai data yang ada dalam satu judul naskah sesuai dengan deskripsi yang di butuhkan.

Penulis membagi data tasybih yang ada dalam manuskrip ini berdasarkan analisis pembahasan pada tiap lembar naskahnya agar mudah merujuk nya kembali pada gambar naskah penelitian yang di tampilkan pada setiap data.

\section{Deskripsi Manuskrip}

Berdasarkan informasi yang di dapat dari bukuSupplement to the catalogue of theArabic Manuscript, kitab "Syarh Fì Bayān al-Majāz wa al-Tasybīh" tersimpan dalam koleksi manuskrip Perpustakaan Nasional RI pada file no. A.504, penulis naskah ini tidak di sebutkan secara jelas/anonyms.Dalam kondisi seperti ini, peneliti melanjutkan tahapan yang di sarankan dalam proses penyuntingan naskah, yaitu analisis judul dan penulis utama teks melalui beberapa teknis: melihat lembar pertama teks, lembar muqaddimah teks, lembar penutup teks dan informasi dari katalog manuskrip lainnya. Proses tersebut di lakukan untuk menemukan kepastian kondisi naskah ini secara jelas berdasarkan penelitian dan bukan anggapan semata.

Secara utuh naskah ini berjumlah 67 lembar, terdiri dari dua sisi (bolak balik), di mulai dari no.272-339, 15 baris per halaman, kecuali pada lembar pertama dan akhir teks. Data tasybih yang menjadi bahan analisis penulis di mulai pada file no. DC290-DC293, berjumlah total 4 (empat) lembar naskah dengan asumsi 4x@2halaman=8 halaman. Kitab ini di berjudul "Syarh Fì Bayān al-Majāz wa al-Tasybīh wa al-Kinayah" sebagaimana yang tertulis di lembar muqaddimah teks. tiap halaman teks di penuhi oleh komentar panjang terkait tema inti yang ada dalam teks inti dan biasanya lembar kanan kiri halaman (hasyiyah) yang kosong di penuhi dengan pembahasan tema inti berdasarkan sudut pandang beberapa tokoh/pakar di bidangnya.

Sebagaimana judul lengkap teks adalah "Syarh $F \bar{l}$ Bayān al-Majāz wa al-Tasybīh wa alKinayah", maka tema yang di bahas dalam kitab ini adalah 3 (tiga) bidang ilmu bayan yaitu majaz, tasybih dan kinayah.

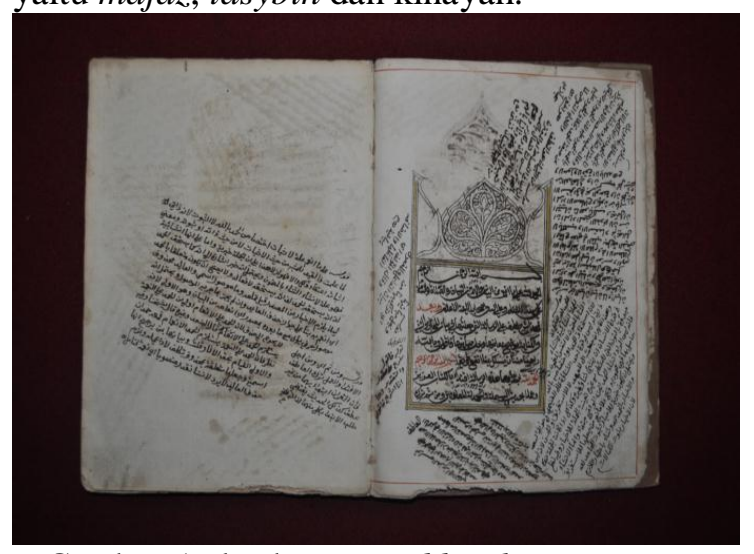

Gambar. 1 : lembar muqaddimah yang memuat judul naskah 


\section{Tahap Analisis Judul dan Penulis Utama Teks}

Rujukan peneliti berdasarkan file naskah A.504, lembar muqaddimah yang menuliskan judul teks ada pada file no.halaman DC.0276. Pada halaman ini penulis teks mengatakan bahwa kitab konten (matan) ini berjudul : "Risālah Lathīfah $F \bar{l}$ bayān al-Majāz wa alTasybīh wa al-Kināyah", dan tidak ada nama penulisnya. Sedangkan pada lembar utama teks, penulis membuat pernyataan bahwa kitabnya ini merupakan kitab komentar (syarh) dari kitab konten (matan) yang beliau tulis sebelumnya. Dengan demikian, kitab ini memperlihatkan dua jenis karakter tersebut dengan memberikan penanda khusus untuk membedakan antara matan dan syarh,yaitu menuliskan teks matan dengan tinta merah dan syarh dengan tinta hitam. Lalu di sempurnakan dengan kata pembuka dan kalimat syukur, tidak tertera nama penulis utama teks.

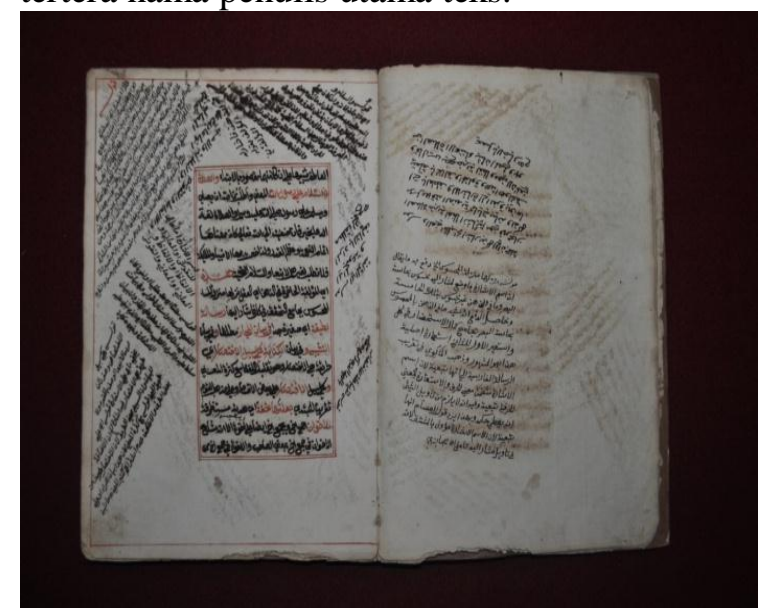

Gambar.2 : Lembar pertama penjelasan seputar judul naskah yang merupakan naskah komentar dari naskah konten sebelumnya yang beliau tulis

\section{Analisis tasybih dalam Manuskrip \\ Data1 DC290 (Pengertian tasybih dan kategori tharafain)}

Pada lembar file naskah DC290, teori tasybih di mulai setelah pembahasan tentang majaz selesai di jelaskan oleh penulis teks, tidak ada fasl/pemisah bab dalam teknik penulisan tersebut. penulis secara langsung menghubungkan pembahasan isti'arah makniyah yang merupakan bagian dari jenis majaz dengan pembahasan tasybih, rukunnya, dan definisi singkat dari masing-masing rukun tersebut. Dalam penjelasan yang sangat singkat tentang tasybih, rukun dan kategorinya. Penulis memberikan satu contoh sebagai berikut:

$$
\text { زيد كالبدر في الحسن : - ن }
$$

Uraian penulis tentang contoh di atas, adalah :

Kataيدjsebagai musyabbah (yang di serupakan), al-badr sebagai musyabbah bih (yang di serupai), s sebagai adat al-tasybih (perangkat penyerupaan), الحسنsebagai wajh al-syibh (kesamaan sifat yang ada pada tharafain)

Penulis lalu menyempurnakan penjelasan contoh di atas dengan menguraikan jenis tharafain, yaitu bahwa adakalanya tharafain terdiri hissiyain, yaitu sifat yang dapat di rasakan oleh salah satu panca indera seperti penglihatan, pendengaran, penciuman, sentuhan, dan rasa. Maka dari contoh di atas kata زليدالبدارadalah hissiyain. Dan adakalanya tharafain terdiri dari 'aqlain, yaitu sifat yang tidak dapat di rasakan oleh salah satu panca indera namun dapat kita temukan melalui pemikiran dan analogi.

Contoh yang tertera dalam teks adalah :

العلم كالحياة

Kataمeduanya adalah perkara yang hanya dapat di temukan maknanya melalui pemikiran dan analogi.

Pada akhir pembahasan tentang kategori tharafain ini, penulis teks memberikan contoh tentang tasybih maqlub, yaitu tasybih yang bermakna hiperbola dari tujuan tasybih pada umumnya, seperti :

$$
\text { النور كالعلم العلم نور }
$$
Masuk pada pembahasan wajh al-syibh dan jenisnya. Penulis teks menyatakan bahwa wajh sibh kadangkala bersifat tunggal seperti kata $a l$ syuja' dalam kalimat :

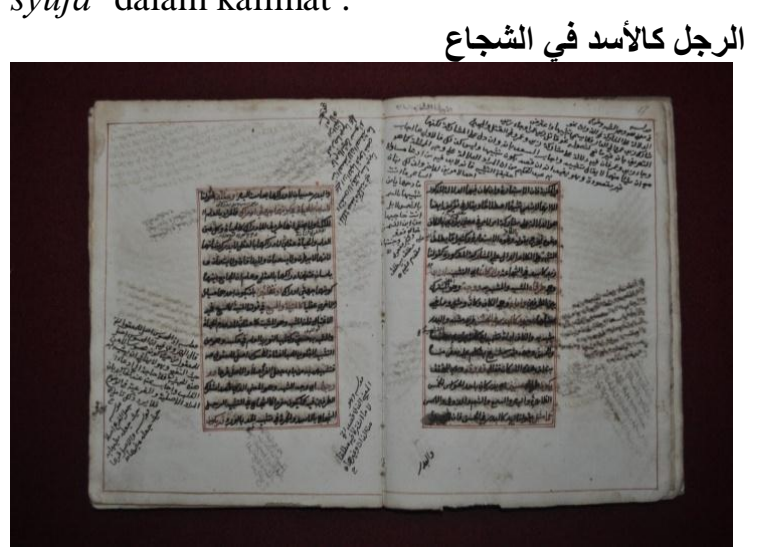

Gambar. 3 : Lembar Data 1

\section{Data 2 DC291 (kategori wajh al-syibh)}

Pada data DC291 ini, penulis teks memberikan beberapa contoh dari masing-masing kategori wajh al-syibh berikut dengan penjelasannya secara rinci, termasuk contoh kategori wajh al- 
syibh yang tidak bersifat tunggal meskipun tharafain nya terdiri dari perkara tunggal. Namun, penyampaian penulis tentang kategorikategori tersebut tidak terstruktur dengan baik sehingga siapapun yang membaca teks ini akan kesulitan memilah materi yang sebenarnya ingin di sampaikan oleh penulis teks kecuali sebelumnya telah mempelajari tema-tema ini dengan baik dan membuat spesifikasi lebih terstruktur.

Contoh kategori wajh al-syibh yang murakkab dari tharafain yang mufrad:

$$
\text { وقد لاج في الصبح الثريا كما يرى كمنقود ملاحية حين نور }
$$

Tharafainnya tunggal, terdiri dari kata منقود الثريا sebagai musyabbah bih nya. Sedangkan perkara yang mengikatkan diri dengan tharafain وقد لاج في الصبح الثريا كما tersebut seperti kalimat كمنقود ملاحية حين نور dan kalimat, tidaklah merubah kategori ketunggalannya.

Sampai akhir teks pada halaman ini, penulis hanya menjelaskan tentang pembagian kategori wajh al-syibh yang di bagi ke dalam beberapa kondisi, seperti :

1. Wajh al-syibh nya murakkab, tharafain nya mufrad: seperti di bahas pada contoh di atas

2. Wajh al-syibh nya murakkab. tharafain nya juga murakkab

3. Wajh al-syibh nya murakkab, tharafain nya mukhtalifain (salah satunya mufrad dan lain nya murakkab).

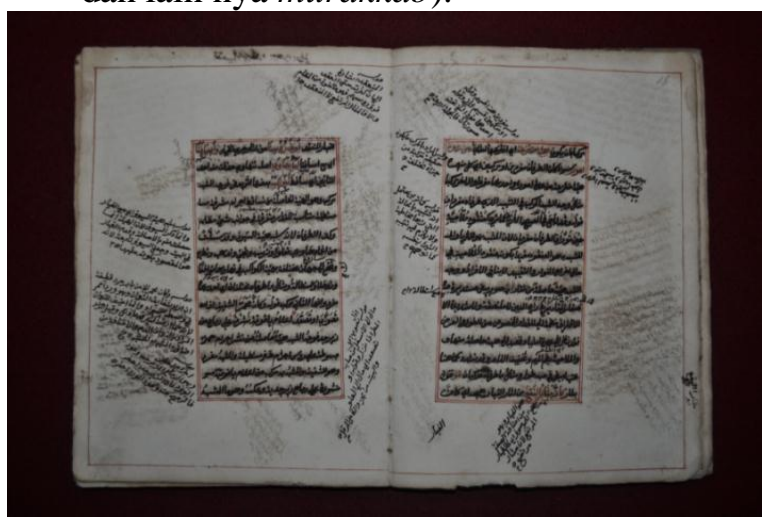

Gambar. 4 : Lembar Data 2

\section{Data 3 DC292 (Pendapat Umum Tentang Wajh Al-syibh)}

Pada seperempat tulisan pertama DC292, penulis teks masih melanjutkan penjelasan seputar kategori wajh al-syibh berikut dengan masing-masing contohnya. Baru setelah itu masuk pada komentar tentang kondisi ungkapan tasybih yang memiliki kecenderungan membuang wajh al-syibh nya. seperti contoh :

$$
\text { زيد في البدر }
$$

Contoh tersebut adalah ungkapan tasybih yang membuang wajh al-syibh nya atau dengan kata lain tasybih ini di beri nama sebagai tasybih mujmal.

Dan jika wajh al-syibh nya di sebutkan, maka di beri nama tasybih mufashal, seperti contoh :

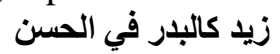

Penulis melanjutkan kategori tasybih yang membuang adat tasybih dan wajh syibhnya, di beri nama tasybih baligh, seperti contoh :

Di sempurnakan dengan definisi tasybih muakkad, yaitu tasybih yang membuang adat tasybihnya, seperti halnya tasybih mursal yaitu yang di sebutkan adat tasybihnya.

Pada akhir lembar DC292 ini, penulis mengulang pembahasan tentang di sebutkannya wajh al-syibh dalam ungkapan dengan istilah dan mana lain, seperti nama tasybih qariban mubtadzilan untuk tasybih mufashal, dan tasybih ghariban untuk tasybih mujmal.

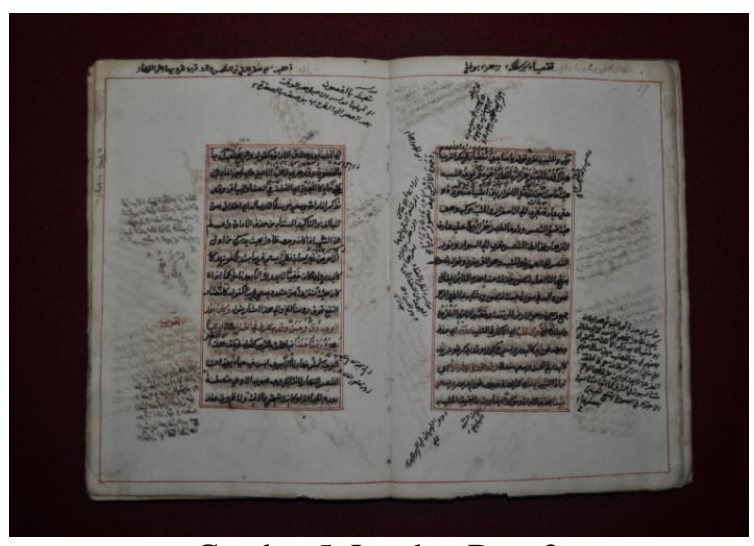

Gambar.5. Lembar Data 3

\section{Data 4 DC293}

Pada halaman pertama file data ini, penulis teks melengkapinya dengan pembahasan contoh tasybih gharibandan dantasybih qariban mubtadzilan. Tidak banyak materi baru yang di bahas pada file data ini, karena di lanjutkan dengan pembahasan isti'arah. Isti'arah di bahas dua kali, yaitu pada saat pembahasan majaz di awal DC. (lihat gambar.6) 


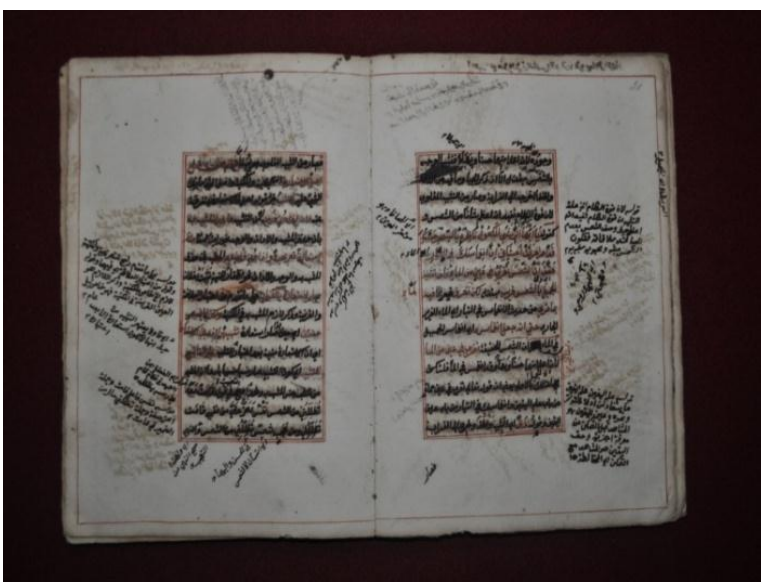

Gambar.6 : Lembar data 4

\section{SIMPULAN DAN SARAN}

\section{Simpulan}

Dari uraian analisis peneliti di atas tentang tema tasybih yang ada pada manuskrip nusantara berjudul "Syarh Fì Bayān al-Majāz wa al-Tasybīh wa al-Kinayah", berikut ini adalah kesimpulan penelitian yang dapat peneliti sajikan :

1. Berdasarkan analisis judul naskah melalui penelusuran metodologi filologi, maka secara lengkap penulis teks menyebutkannya dengan judul "SyarhFi Bayān al-Majāz wa al-Tasybīh wa alKināyah". Kitab ini merupakan kitab komentar (syarh) atas kitab sebelumnya yang juga I tulis oleh penulis teks yang sama berjudul " Risālah Lathīfah Fī bayān al-Majāz wa al-Tasybīh wa al-Kināyah. Berjumlah total 67 lembar, dua sisi (bolak balik),terdiri dari 15 baris untuk masingmasing halaman nya kecuali pada lembar pembuka, halaman judul, dan lembar ikhtitam/penutup. Tidak ada informasi seputar penulis teks dan tahun penulisan teks. Naskah ini bernomor file A.504, tersimpan dalam koleksi manuskrip nusantara di Perpustakaan Nasional RI, Salemba-Jakarta.

2. Naskah ini adalah naskah skrip Arab yang di tulis berbahasa Arab dan besar dugaan bahwa penulisnya adalah pakar bahasa Arab Timur Tengah. Dasar dugaan tersebut muncul dari gaya penulisan yang muncul pada teks konten yang dominan di pakai oleh para penulis Arab, seperti : (1) teks konten berwarna merah, sedangkan teks komentar berwarna hitam. (2) komentar-komentar yang muncul memenuhi halaman kanan kiri yang kosong (hasyiyah) berbahasa Arab dan merupakan pelengkap dari teks konten yang ada, ini juga bagian dari tradisi penulisan Arab. (3) tanda baca dalam penulisan yang secara konsisten menggunakan tanda baca yang biasa di letakkan oleh penulis Arab, seperti penggunaan صح di atas kata yang benar untuk menyatakan koreksian pada kata yang salah sebelumnya, lalu peletakan satu kata di footer tiap halaman akhir sebagai penanda halaman tersebut terhubung dengan halaman selanjutnya pada lembar berikutnya dan ini biasa di sebut dengan ta'qibah.

3. Penulisan materi tasybih yang ada pada manuskrip ini tidak terstruktur dengan baik, buktinya adalah beberapa materi terualang dalam beberapa halaman teks seperti materi isti'arah yang ada pada pembahasan majaz dan di sebutkan kembali pada pembahasan tasybih, juga dengan contoh dan analisis yang sama persis. Lebih dari itu, pembagian jenis tasybih tidak lengkap, peneliti tidak menemukan pembahsan tentang jenis tasybih dhimni yang seharusnya muncul berdampingan dengan jenis tasybih maqlub, juga jenis tasybih tamtsil dan ghair tamtsil yang sama sekali tidak di bahas dalam naskah ini. padahal jenisjenis tasybih tersebut adalah informasi penting dan mendasar untuk pengetahuan pembelajar ilmu balaghah.

4. Contoh-contoh yang di hadirkan oleh penulis teks sebenarnya sangat detail dari masing-masing kategori, hanya saja beberapa contoh adalah pengulangan dari yang sebelumnya. Artinya, diksi yang di gunakan sangat terbatas dan rasanya tidak mewakili kebiasaan gaya para penulis Arab pada umumnya.

\section{UCAPAN TERIMA KASIH}

TERHATUR TERIMA KASIH KEPADA LP2M UNIVERSITAS AL-AZHAR INDONESIA YANG TELAH MEMBERIKAN DUKUNGAN PENUH SEHINGGA PENELITIAN INI DAPAT TERLAKSANA SESUAI RENCANA DAN TARGET 


\section{DAFTAR PUSTAKA}

[1]. Jarim, Ali dan Musthafa, Al-Balaghah alWadhihah, maktabah al-Mishriyah, Cairo, Egypt, 1989

[2]. Al-Munajjid, Shalah al-Din, Qawaid Tahqiq al-Turats, Jami'ah al-Dual alArabiyyah, Mohamdesein, Cairo, Egypy, 1987

[3]. Harun, Abd Salam, Tahqiq al-Nushus wa Nasyruha, Maktabah al-Kahnjiy al'Arabiy, Misr al-Jadid, Cairo, Egypt, 1999

[4]. Rasyid, Mohammed, Al-Madkhal fi 'ilm Al-Balaghah, Maktabah Dār al-Fikr, Lebanon
[5]. Manuskrip Nusantara berjudul " al-Majaz wa al- Tasybih", Perpustakaan Nasioanal RI

[6]. al-Maraghi,Ahmad Mustafa, 'Ulum alBalaghah, Maktabah al-Misr al-Jadidah, Cairo Egypt

[7]. Al-Qazuwaini, Al-Idhah fi al-'Ulum alBalaghah, Dâr el-Fikr, Lubnan

[8]. Al-Jurjani, Abd al-Qaher, Asrar albalaghah, Daar al-Madani, Jeddah, Saudi Arabia, 1999

[9]. Dhayf,Syauqi, al-Adab 'Arabi Fi 'Ashr alJahiliy Wa al-Shodr al-Islami, Daar alFikr, Lebanon 